\title{
Substitute of Expensive Pt with Improved Electro- catalytic Performance and Higher Resistance to CO Poisoning for Methanol Oxidation: the Case of Synergistic Pt- $\mathrm{Co}_{3} \mathrm{O}_{4}$ Nanocomposite
}

\author{
Hongxiao Zhao ${ }^{1, *}, \quad$ Zhi Zheng ${ }^{1, *}, \quad$ Jing $\mathrm{Li}^{1}, \quad$ Huimin $\mathrm{Jia}^{1}, \quad$ Ka-wai Wong ${ }^{2}, \quad$ Yidong Zhang ${ }^{1}$, Woon Ming Lau ${ }^{2}$
}

(Received 17 September 2013; accepted 29 October 2013; published online 16 November 2013)

\begin{abstract}
In this paper, $\mathrm{Pt}-\mathrm{Co}_{3} \mathrm{O}_{4}$ nanocomposite was synthesized by a sol-gel process combined with electrodeposition method. Its electrocatalytic activity towards methanol oxidation was investigated at room temperature using cyclic voltammetry (CV), electrochemical impedance spectroscopy (EIS) and current densitytime curve. It is found that the resultant $\mathrm{Pt}-\mathrm{Co}_{3} \mathrm{O}_{4}$ catalysts with minute amount of $\mathrm{Pt}$ exhibite attractive electrocatalytic activity for methanol oxidation reaction (MOR) but with a high resistance CO poisoning due to the synergistic effects from $\mathrm{Pt}$ and $\mathrm{Co}_{3} \mathrm{O}_{4}$. Together with the low manufacturing cost of $\mathrm{Co}_{3} \mathrm{O}_{4}$, the reported nanostructured $\mathrm{Pt}-\mathrm{Co}_{3} \mathrm{O}_{4}$ catalyst is expected to be a promising electrode material for direct methanol fuel cells (DMFC).
\end{abstract}

Keywords: $\mathrm{Pt}-\mathrm{Co}_{3} \mathrm{O}_{4}$ nanocomposite; MOR; Electrocatalytic activity

Citation: Hongxiao Zhao, Zhi Zheng, Jing Li, Huimin Jia, Ka-wai Wong, Yidong Zhang and Woon Ming Lau, "Substitute of Expensive Pt with Improved Electrocatalytic Performance and Higher Resistance to CO Poisoning for Methanol Oxidation: the Case of Synergistic Pt-Co $\mathrm{O}_{4}$ Nanocomposite", Nano-Micro Lett. 5(4), 296-302 (2013). http://dx.doi.org/10.5101/nml.v5i4.p296-302

\section{Introduction}

Methanol oxidation reaction (MOR) has attracted extensive interest due to its potential application in direct methanol fuel cells (DMFCs) [1-2], which are promising systems for portable and residential power applications. However, the technically critical drawbacks of DMFC are the low catalytic activity and efficiency in methanol electro-oxidation, and severe poisoning of the anode by intermediates, in particular CO. Thus, an electrocatalyst for MOR with a higher activity at room temperature is imperatively needed to enhance DMFC's performance for commercial applications [3]. Tremendous research has been made towards different electrocatalysts for MOR in recent years [4-7], especially those on Pt-base electrocatalysts. It is well known that Pt-containing electrocatalyst has two main disadvantages of (i) high material cost, and (ii) severe poisoning by the intermediates or CO-like species. Some metals, such as palladium and osmium [8-11], have been proposed as alternatives. However, they are also precious metals and use of them does not help reduce the manufacturing cost. On the other hand, the activity of the electrocatalyst other than noble metal is generally lower than that of the Pt-based catalysts [12]. Therefore, Pt-based catalysts still remain as the most optimal electrocatalysts for MOR [13-14]. Recently, promising results have been achieved by blending $\mathrm{Pt}$ with metal

\footnotetext{
${ }^{1}$ Key Laboratory of Micro-Nano Materials for Energy Storage and Conversion of Henan Province, Institute of Surface Micro and Nano Materials, Xuchang University, Henan 461000 China

${ }^{2}$ Chengdu Green Energy and Green Manufacturing R\&D Center, Sichuan 610207 China

*Corresponding author. E-mail: zhaoxiao124@126.com
} 
oxides such as $\mathrm{CeO}_{2}$ and $\mathrm{MnO}_{2}$. For example, Takahashi et al [15] found that the electrocatalytic activity of Pt-CeO $/$ carbon black (CB) for MOR and its performance as anodo was superior to commercially available Pt-Ru/C materials. Yang et al [16] found that $\mathrm{Pt}$ nanoparticles on $\mathrm{Mn}_{3} \mathrm{O}_{4}$-modified MWCNTs showed excellent electrocatalytic properties and excellent stability toward to MOR, implying that metal oxides can play a key role in enhancing MOR.

Among various metal oxides, $\mathrm{Co}_{3} \mathrm{O}_{4}$ was considered as the most active catalyst for CO oxidation [17-19]. Therefore, addition of $\mathrm{Co}_{3} \mathrm{O}_{4}$ into the Pt-based electrodes is expected to be able to improve the catalytic performance by effectively reducing the amount of $\mathrm{CO}$ as a poisoning species. Recently, $\mathrm{Xu}$ et al [20] observed that $\mathrm{Co}_{3} \mathrm{O}_{4}$ promoted electro-oxidation reactions of methanol, ethanol, ethylene glycol and glycerol on $\mathrm{Pd} / \mathrm{C}$ in alkaline media. However, a substantial amount of noble metal was still required. In this paper, $\mathrm{Pt}-\mathrm{Co}_{3} \mathrm{O}_{4}$ nanocomposites with a low $\mathrm{Pt}$ content are obtained by a two-step method. The resultant nanocomposite as the catalyst for MOR as well as their electrochemical performance, chemical composition, crystallinity and morphology are evaluated by electrochemical technique, X-ray diffraction (XRD), X-ray photoelectron spectroscopy (XPS), scanning electron microscopy (SEM), transmission electron microscopy (TEM) and high-resolution transmission electron microscopy (HRTEM) analyses. Electrocatalytic activities of electrodes based on such $\mathrm{Pt}-\mathrm{Co}_{3} \mathrm{O}_{4}$ nanocomposites for methanol electro-oxidation are investigated by $\mathrm{CV}$, EIS and current density-time experiments. It is observed that the prepared $\mathrm{Pt}-\mathrm{Co}_{3} \mathrm{O}_{4}$ nanocomposites exhibited excellent electrocatalytic activities towards MOR.

\section{Experimental}

\section{Synthesis of $\mathrm{Co}_{3} \mathrm{O}_{4}$ nanoparticles}

All solutions were prepared by using analytical grade chemical reagents and double distilled water. In the present study, $\mathrm{Co}_{3} \mathrm{O}_{4}$ nanoparticles were synthesized by a sol-gel method. The reaction mixture included $\mathrm{Co}\left(\mathrm{NO}_{3}\right)_{2} \cdot \mathrm{H}_{2} \mathrm{O}$ and citric acid in a molar ratio of $1: 2$, and the $\mathrm{pH}$ of the solution was adjusted to 5 . The precursor formed was calcinated at $600^{\circ} \mathrm{C}$ for $3 \mathrm{~h}$ and then crushed into fine powder. The $\mathrm{Co}_{3} \mathrm{O}_{4}$ nanoparticles collected were dispersed with polytetrafluoroethylene (PTFE) as a binder in anhydrous ethanol. The mixture was then daubed on the kryptol, and then dried in a vacuum oven.

\section{Synthesis of $\mathrm{Pt}-\mathrm{Co}_{3} \mathrm{O}_{4}$ nanoparticles}

Prior to all electrochemical experiments, the solution in the electrochemical cell was degassed by bubbling $\mathrm{N}_{2}$ for 20 min. Upon the prepared electrode with $\mathrm{Co}_{3} \mathrm{O}_{4}$ nanoparticles, $\mathrm{Pt}$ was electrodeposited at the potential range from $-0.3 \mathrm{~V}$ to $0.2 \mathrm{~V}$ at $50 \mathrm{mV} / \mathrm{s}$ for certain segments in a solution of $5 \mathrm{mM} \mathrm{H}_{2} \mathrm{PtCl}_{6}$ and $0.5 \mathrm{M}$ $\mathrm{H}_{2} \mathrm{SO}_{4}$. As a control, pure $\mathrm{Pt}$ electrode was prepared under the same conditions on the bare kryptol. The resultant $\mathrm{Pt}-\mathrm{Co}_{3} \mathrm{O}_{4}$ nanocomposite and $\mathrm{Pt}$ electrode were then directly used as the working electrode for MOR.

\section{Analysis and measurement}

Electrochemical experiments were carried out in a conventional three-electrode cell with a CHI 660D electrochemical workstation. The working electrode was kryptol. A Pt wire and a saturated calomel electrode (SCE) were used as the counter and reference electrodes respectively. The electrocatalytic properties of $\mathrm{Pt}-\mathrm{Co}_{3} \mathrm{O}_{4}$ nanocomposite was studied in $\mathrm{CH}_{3} \mathrm{OH}$ solution of $\mathrm{H}_{2} \mathrm{SO}_{4}$ since $\mathrm{H}_{2} \mathrm{SO}_{4}$ is extensively used as electrolyte in DMFCs. The impedance data were collected with a frequency range from $1 \mathrm{~Hz}$ to $100 \mathrm{kHz}$ of $\mathrm{AC}$ amplitude of $5 \mathrm{mV}$. The electrochemical active surface area (ECSA) of the $\mathrm{Pt}$ and $\mathrm{Pt}-\mathrm{Co}_{3} \mathrm{O}_{4}$ nanocomposite were measured in a nitrogen saturated $0.5 \mathrm{M} \mathrm{H}_{2} \mathrm{SO}_{4}$ aqueous solution, and the potential was scanned from -0.2 to $0.8 \mathrm{~V}$ (vs SCE) at a sweep rate of $10 \mathrm{mV} / \mathrm{s}$. CVs were obtained after 50 cycles. All experiments were carried out at room temperature.

XRD measurement was performed by a Rigaku D/MAX-RB diffractometer with a $\mathrm{Cu}-\mathrm{K} \alpha$ radiation $(\lambda$ $=0.15418 \mathrm{~nm})$. XPS measurements were performed with a VG Scientific ESCALAB Mark II spectrometer equipped with two ultrahigh vacuum (UHV) chambers. All binding energies were referenced to the $\mathrm{C} 1 \mathrm{~s}$ peak at $284.6 \mathrm{eV}$ of the surface adventitious carbon. The morphology of the synthesized nanomaterials was studied using a SEM operating at $15 \mathrm{kV}$, a transmission electron microscope (TEM, Philip CM-120) and highresolution transmission electron microscopy (HRTEM, JEOL JEM 2100) operated at $200 \mathrm{kV}$.

\section{Results and discussion}

\section{XRD and XPS analysis}

The XRD spectra of the prepared $\mathrm{Co}_{3} \mathrm{O}_{4}$ and Pt$\mathrm{Co}_{3} \mathrm{O}_{4}$ samples are shown in Fig. $1 . \mathrm{Co}_{3} \mathrm{O}_{4}$ can be readily identified in both the pure nanoparticles and $\mathrm{Pt}-\mathrm{Co}_{3} \mathrm{O}_{4}$ nanocomposite because all diffraction peaks can be indexed to $\mathrm{Co}_{3} \mathrm{O}_{4}$ and matched well with the cubic crystal structure (JCPDS file No. 42-1467, Fd3m). However, the typical diffraction peaks for $\mathrm{Pt}$ cannot be observed in the XRD pattern of $\mathrm{Pt}-\mathrm{Co}_{3} \mathrm{O}_{4}$ nanocomposites (Fig. 1(b)), implying that the Pt content in Pt$\mathrm{Co}_{3} \mathrm{O}_{4}$ nanoparticles is very low. By using the Scher- 
rer's equation, the average diameter of as-prepared $\mathrm{Co}_{3} \mathrm{O}_{4}$ particles is about $35 \mathrm{~nm}$.

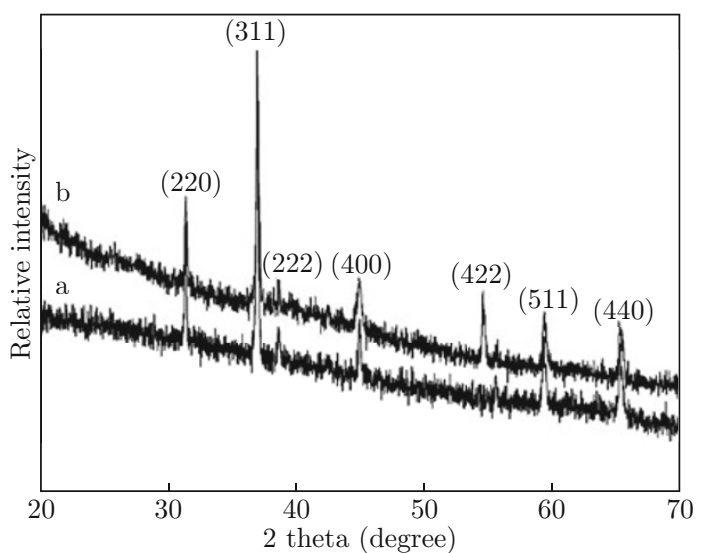

Fig. 1 XRD spectra of (a) $\mathrm{Co}_{3} \mathrm{O}_{4}$ nanoparticles; (b) Pt$\mathrm{Co}_{3} \mathrm{O}_{4}$ nanocomposite.
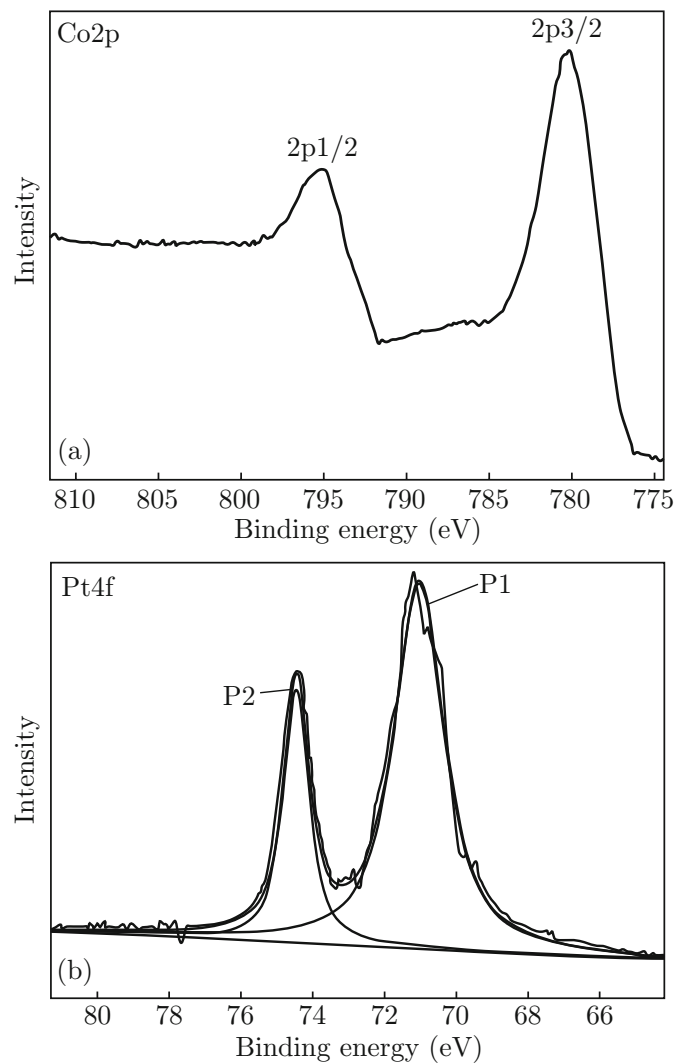

Fig. 2 XPS Co 2p and $\mathrm{Pt} 4 \mathrm{f}$ core level emission of $\mathrm{Pt}-\mathrm{Co}_{3} \mathrm{O}_{4}$ nanocomposite.

Considering $\mathrm{Pt}$ is electrodeposited when $\mathrm{Co}_{3} \mathrm{O}_{4}$ is formed, it may be attached on $\mathrm{Co}_{3} \mathrm{O}_{4}$ surface. The XPS characterization of the samples is further performed to identify the presence of $\mathrm{Pt}$ in $\mathrm{Pt}-\mathrm{Co}_{3} \mathrm{O}_{4}$ particles. Figure 2 shows the XPS spectra of the Co $2 \mathrm{p}$ and $\mathrm{Pt} 4 \mathrm{f}$ core level. The XPS Pt $4 \mathrm{f}$ core level (Fig. 2(b)) was observed at the binding energies of around $71.0 \mathrm{eV}(\mathrm{Pt}$
$4 \mathrm{f} 7 / 2$ ) and $74.4 \mathrm{eV}(\mathrm{Pt} 4 \mathrm{f5} / 2)$, which is in good agreement with that in elemental Pt. The XPS Co $2 \mathrm{p}$ core level spectrum (Fig. 2(a)) also showed respectively two peaks at binding energy of $780.0 \mathrm{eV}$ and $795.1 \mathrm{eV}$, suggesting the presence of $\mathrm{Co}$ in metal oxide form. The atomic ratio of $\mathrm{Pt}$ to $\mathrm{Co}$ of the particle surface was calculated to be around 3:97 by XPS, which was confirmed by energy dispersive X-ray analysis (EDX, Fig. 3(b)). It also confirms a relative low content of Pt.

\section{SEM, TEM and HRTEM images}

The SEM and TEM micrographs of the synthesized Pt- $\mathrm{Co}_{3} \mathrm{O}_{4}$ nanocomposites are shown in Fig. 3. The as-prepared samples were aggregated severely so that the particles were difficult to be identified in SEM (Fig. 3(a)). However after sonication, spherical nanoparticles could be clearly seen in TEM and the average diameter of these nanoparticles were estimated to be $50-60 \mathrm{~nm}$ (Fig. 3(c)), which is comparable to the value determined by XRD. The inset of Fig. 3(c) shows the selected area electron diffraction (SAED) pattern that was recorded from an individual $\mathrm{Pt}-\mathrm{Co}_{3} \mathrm{O}_{4}$ nanoparticle that exhibits good crystallinity. The HRTEM images (Fig. 3(d)) show the clearly resolved lattice fringes, corresponding to the (222) planes of $\mathrm{Pt}$ and (440), (731) plans of $\mathrm{Co}_{3} \mathrm{O}_{4}$, respectively. These substantiate that the presence of $\mathrm{Pt}$ particles in the products with high crystallinity.

\section{CV for methanol electro-oxidation}

Figure 4 showed the CVs of kryptol, $\mathrm{Co}_{3} \mathrm{O}_{4}$ electrode, bare $\mathrm{Pt}$ nanostructured electrode and $\mathrm{Pt}-\mathrm{Co}_{3} \mathrm{O}_{4}$ nanocomposite electrode in $0.5 \mathrm{~mol} / \mathrm{L} \mathrm{H}_{2} \mathrm{SO}_{4}+1$ $\mathrm{mol} / \mathrm{L} \mathrm{CH}_{3} \mathrm{OH}$ solution. The shapes of the $\mathrm{CV}$ curves were close to that previously reported with other anode materials [21]. The anodic peaks for MOR appeared on both anodes in forward and reverse sweeps. Peak "f" was obtained from the positive direction scan (forward scan) and Peak "b" from the reverse direction (reversed scan).

The ratio of the forward anodic peak current density to the reverse anodic peak current density $\left(I_{f} / I_{b}\right)$ can be used to describe the catalyst tolerance to carbonaceous species accumulation [16,22-23]. We assigned the ratio of $I_{f} / I_{b}$ as $k$. The current density at the peak potential was taken as one main parameter of the activity of the electrocatalysts for MOR [24]. According to Fig. 4, it is noticed that there was no methanol oxidation on pure $\mathrm{Co}_{3} \mathrm{O}_{4}$ electrode while methanol oxidation on $\mathrm{Pt}-\mathrm{Co}_{3} \mathrm{O}_{4}$ nanocomposite electrode can be observed and the peak current density $\left(I_{f}\right)$ was higher than Pt nanostructured electrode, though only minute amount of $\mathrm{Pt}$ was introduced (atomic ratio of $\mathrm{Pt}: \mathrm{Co}$ is 3:97 as determined by XPS). The $\mathrm{k}$ value of $\mathrm{Pt}-\mathrm{Co}_{3} \mathrm{O}_{4}$ electrode $(k=1.33)$ is around $25 \%$ higher than that 

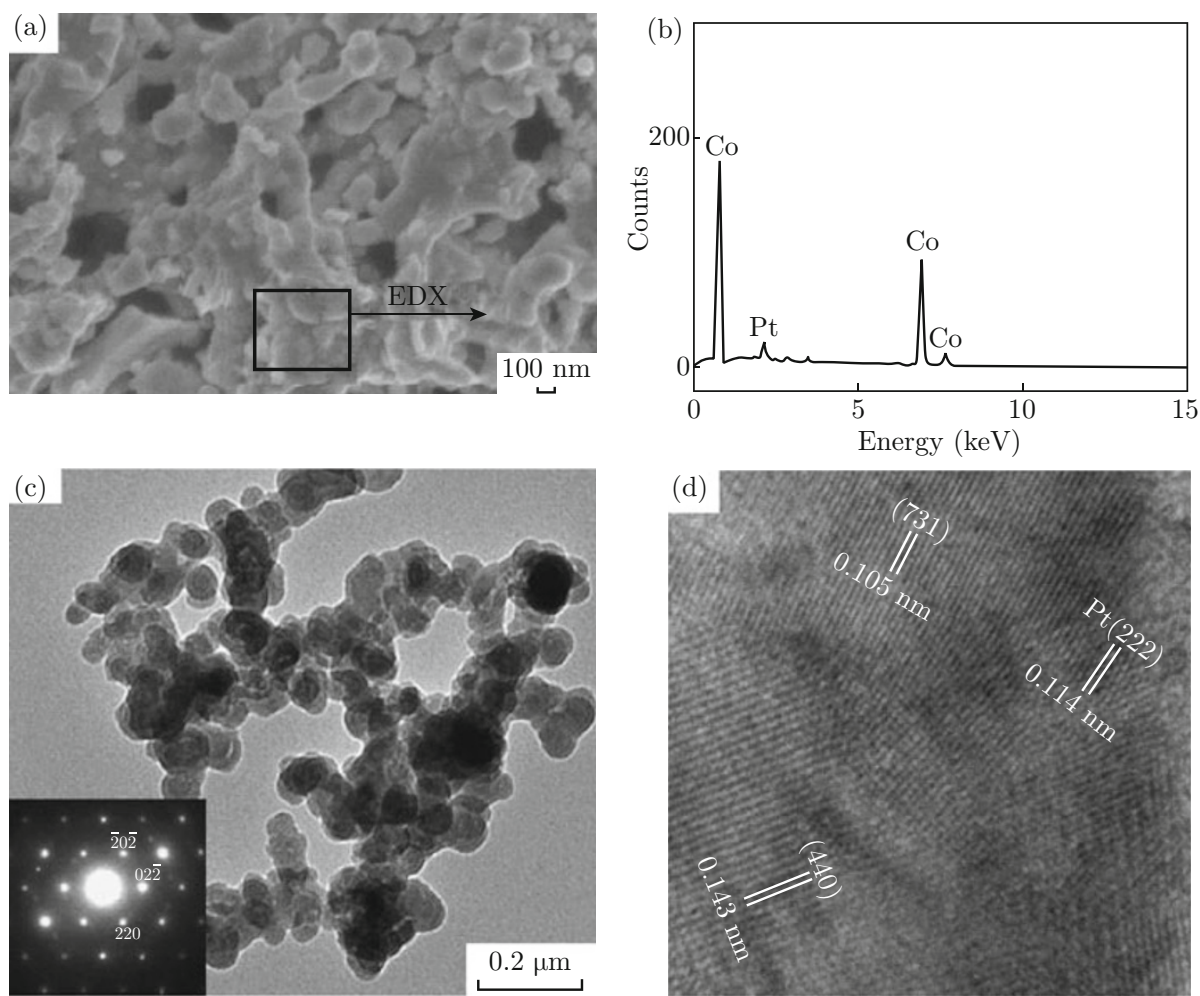

Fig. 3 (a) SEM; (b) EDX; (c) TEM and (d) HRTEM morphologies of $\mathrm{Pt}_{-} \mathrm{Co}_{3} \mathrm{O}_{4}$ nanoparticles (Inset is SAED pattern of $\mathrm{Pt}-\mathrm{Co}_{3} \mathrm{O}_{4}$ nanoparticles).

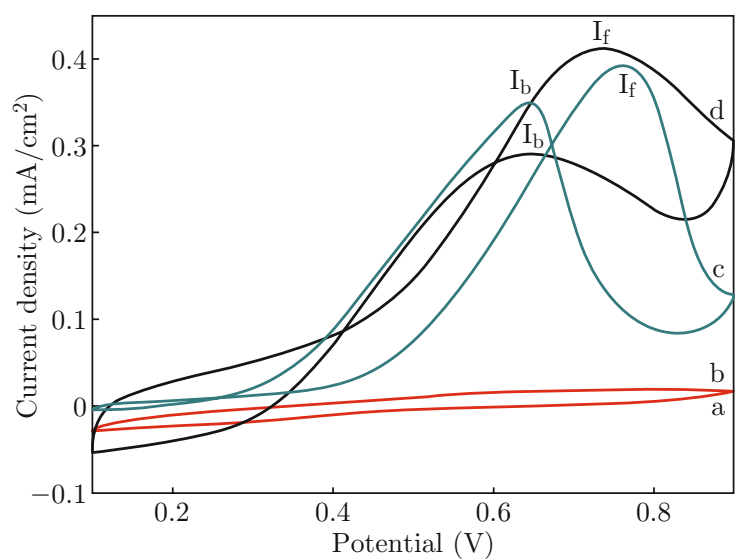

Fig. 4 Cyclic voltammograms for (a) kryptol; (b) $\mathrm{Co}_{3} \mathrm{O}_{4}$ electrode; (c) $\mathrm{Pt}$ electrode and (d) $\mathrm{Pt}-\mathrm{Co}_{3} \mathrm{O}_{4}$ electrode in $0.5 \mathrm{~mol} / \mathrm{L} \mathrm{H}_{2} \mathrm{SO}_{4}+1 \mathrm{~mol} / \mathrm{L} \mathrm{CH}_{3} \mathrm{OH}$ solution obtained at $0.05 \mathrm{~V} / \mathrm{s}$.

of pure Pt nanostructured electrode $(k=1.07)$. It is proposed that though the pure $\mathrm{Co}_{3} \mathrm{O}_{4}$ is not catalytically active towards MOR, the presence of $\mathrm{Co}_{3} \mathrm{O}_{4}$ can enhance the catalytic activity of $\mathrm{Pt}$ by oxidizing the intermediate carbonaceous species to carbon dioxide on $\mathrm{Pt}-\mathrm{Co}_{3} \mathrm{O}_{4}$ electrode.

It has been reported that the mechanism of MOR on Pt nanostructured electrode in acidic medium involves parallel and consecutive oxidation reactions [25], in which "ad" denotes species in adsorbed state, as fol- lows:

$$
\begin{aligned}
& \mathrm{CH}_{3} \mathrm{OH}_{\mathrm{ad}} \rightarrow \mathrm{CO}_{\mathrm{ad}}+4 \mathrm{H}^{+}+4 \mathrm{e}^{-} \\
& \mathrm{CO}_{\mathrm{ad}}+\mathrm{OH}_{\mathrm{ad}} \rightarrow \mathrm{CO}_{2}+\mathrm{H}^{+}+\mathrm{e}^{-}
\end{aligned}
$$

Further oxidation to carbon dioxide is usually difficult on pure $\mathrm{Pt}$ electrodes at room temperature because of the lack of active oxygen on the surface. Both $\mathrm{CO}$ as a poisoning agent and $\mathrm{CO}_{2}$ have been clearly observed by infrared reflectance spectroscopy and gas chromatography [26-27]. The oxidation current density at the peak potential increased when $\mathrm{Co}_{3} \mathrm{O}_{4}$ was added, it appears that the presence of $\mathrm{Co}_{3} \mathrm{O}_{4}$ facilitates the oxidation of freshly chemisorbed species and leads to an enhanced activity for methanol electro-oxidation, in which $\mathrm{Co}_{3} \mathrm{O}_{4}$ provides active oxygen for removal of intermediates such as $\mathrm{CO}$ on the $\mathrm{Pt}$ surface effectively. The mechanism of MOR on $\mathrm{Pt}-\mathrm{Co}_{3} \mathrm{O}_{4}$ electrocatalyst is proposed. The methanol is initially adsorbed on $\mathrm{Pt}$, while simultaneously loses its methanolic proton to a basic oxide ion. Then the methoxy species formed get oxidatively decomposed to $\mathrm{CO}$ species and this strongly bound intermediate is expected to be removed from the electrocatalyst surface by the reaction with $\mathrm{Co}_{3} \mathrm{O}_{4}$. $\mathrm{CO}$ was suggested to be adsorbed on oxidized cobalt site, probably $\mathrm{Co}^{3+}[28]$, and the adsorbed $\mathrm{CO}$ reacts with oxygen linked to the active $\mathrm{Co}^{3+} \cdot \mathrm{CO}_{2}$ is formed and desorbed quickly [29]. This process can be described by 
the following equation:

$$
\mathrm{Co}^{3+} \mathrm{O}_{\text {surface }}+\mathrm{CO}_{\mathrm{ads}}+\mathrm{e}^{-} \rightarrow \mathrm{Co}^{2+}+\mathrm{CO}_{2}
$$

\section{EIS for methanol electro-oxidation}

Figure 5 shows the electrochemical impedance spectroscopy of $\mathrm{Pt}$ and $\mathrm{Pt}-\mathrm{Co}_{3} \mathrm{O}_{4}$ electrode in $1 \mathrm{~mol} / \mathrm{L}$ $\mathrm{CH}_{3} \mathrm{OH}+0.5 \mathrm{~mol} / \mathrm{L} \mathrm{H}_{2} \mathrm{SO}_{4}$ aqueous solution. The impedance spectra display a depressed semi-circle in the high frequency region and a straight line with a slope of nearly $45^{\circ}$ in the low frequency region. In comparison with the impedance spectra shown in Fig. 5(a), it is found that the diameter of the semi-circle in Fig. 5(b) declines greatly. In other words, the charge transfer resistance $(R c t)$ of the $\mathrm{Pt}-\mathrm{Co}_{3} \mathrm{O}_{4}(1.607 \Omega)$ is much lower than that of $\mathrm{Pt}(34.55 \Omega)$. This means that the presence of $\mathrm{Co}_{3} \mathrm{O}_{4}$ nanoparticles in $\mathrm{Pt}-\mathrm{Co}_{3} \mathrm{O}_{4}$ electrode leads to a faster charge transfer in the $\mathrm{Pt}-\mathrm{Co}_{3} \mathrm{O}_{4}$-solution electrode-solution interface than at the Pt-solution interface for $\mathrm{Pt}$ nanostructured electrode, contributing to the enhanced $\mathrm{MOR}$ exhibited by $\mathrm{Pt}-\mathrm{Co}_{3} \mathrm{O}_{4}$ nanocomposite.

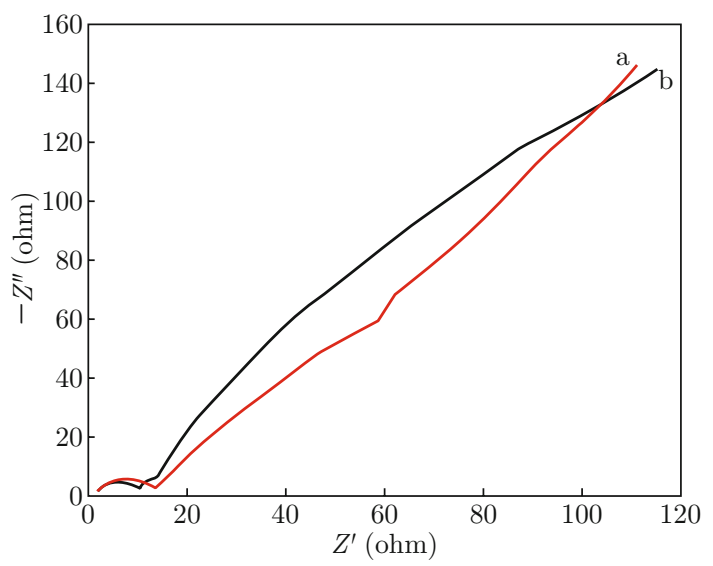

Fig. 5 EIS of (a) Pt; (b) $\mathrm{Pt}-\mathrm{Co}_{3} \mathrm{O}_{4}$ electrode in $1 \mathrm{~mol} / \mathrm{L}$ $\mathrm{CH}_{3} \mathrm{OH}+0.5 \mathrm{~mol} / \mathrm{L} \mathrm{H}_{2} \mathrm{SO}_{4}$ aqueous solution.

\section{Current density-time curves for methanol electro-oxidation}

Figure 6 shows the typical current density-time curves obtained in $1 \mathrm{M} \mathrm{CH} \mathrm{CH}_{3} \mathrm{OH}+0.5 \mathrm{M} \mathrm{H}_{2} \mathrm{SO}_{4}$ solution at an anodic potential of $0.7 \mathrm{~V}$ for $\mathrm{Pt}$ and $\mathrm{Pt}$ $\mathrm{Co}_{3} \mathrm{O}_{4}$ electrodes. This applied potential was chosen because it was close to the oxidation potential as revealed from CVs (Fig. 4). It can be seen that both samples show current density decay in current densitytime measurements. There is an initial current density drop, followed by a slower decay. However, the current density values obtained from $\mathrm{Pt}-\mathrm{Co}_{3} \mathrm{O}_{4}$ are higher than that from $\mathrm{Pt}$ electrode, indicating that $\mathrm{Pt}-\mathrm{Co}_{3} \mathrm{O}_{4}$ electrode has a better $\mathrm{CO}$ resistance than pure $\mathrm{Pt}$. This result is consistent with the above $\mathrm{CV}$ results.

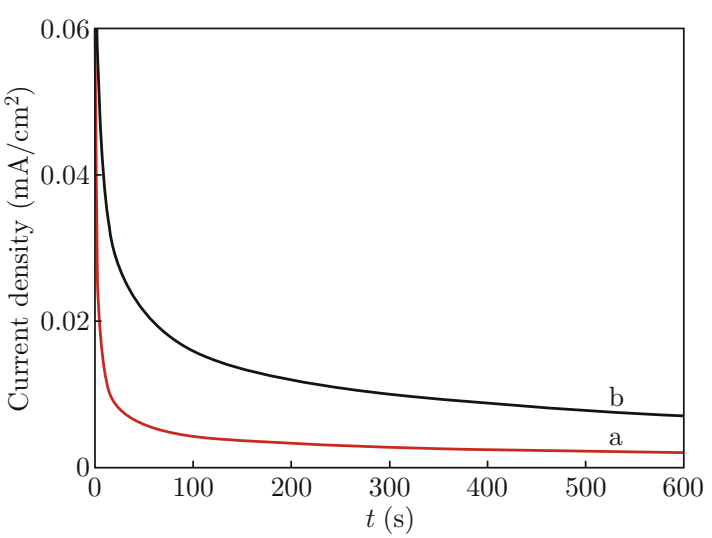

Fig. 6 Current density-time curves at $0.7 \mathrm{~V}$ for (a) Pt; (b) $\mathrm{Pt}-\mathrm{Co}_{3} \mathrm{O}_{4}$ electrode in $1 \mathrm{M} \mathrm{CH} 3 \mathrm{OH}$ and $0.5 \mathrm{M} \mathrm{H}_{2} \mathrm{SO}_{4}$.

\section{Conclusions}

The Pt- $\mathrm{Co}_{3} \mathrm{O}_{4}$ nanocomposite electrode was successfully prepared by a two-step method. The results of CV measurement imply a higher electrocatalytic activity for $\mathrm{MOR}$ on $\mathrm{Pt}-\mathrm{Co}_{3} \mathrm{O}_{4}$ nanocomposite electrode than pure $\mathrm{Pt}$ nanostructured electrode. The current-time experiment demonstrated that $\mathrm{Pt}-\mathrm{Co}_{3} \mathrm{O}_{4}$ nanocomposite electrode showed good resistance to $\mathrm{CO}$ poisoning due to the presence of $\mathrm{Co}_{3} \mathrm{O}_{4}$. The impact of the current research work is that the obtained $\mathrm{Pt}-\mathrm{Co}_{3} \mathrm{O}_{4}$ nanocomposite electrode can not only enhance the electrochemical activity and resistance to catalysts poisoning, but also reduce the cost of the electrodes because of the introduction of low-cost $\mathrm{Co}_{3} \mathrm{O}_{4}$. These two advantages are crucial to the realistic application of DMFC. The $\mathrm{Pt}-\mathrm{Co}_{3} \mathrm{O}_{4}$ nanocomposite electrode is thus expected to be a promising candidate as electrode material of DMFC.

\section{Acknowledgements}

This work was supported by National Natural Science Foundation of China (Grant No. 21273192, 91023010, 61204009, 21303153), Innovation Scientists and Technicians Troop Construction Projects of Henan Province (Grant No. 104100510001), the Program for Science \& Technology Innovation Talents in Universities of Henan Province (2008 HASTIT016), and Henan Province Science and Technology Key Project (Grant No. 082102230036 and 122102210479). The authors would like to thank the support from the China Academy of Engineering Physics, and Chengdu Science \& Technology Development Center.

\section{References}

[1] M. Islam, R. Basnayake and C. Korzeniewski, "A study of formaldehyde formation during methanol 
oxidation over $\mathrm{PtRu}$ bulk alloys and nanometer scale catalyst", J. Electroanal. Chem. 599(1), 3140 (2007). http://dx.doi.org/10.1016/j.jelechem. 2006.08.010

[2] J. Q. Kang, W. T. Ma, J. J. Wu and M. Pan, "A novel catalyst Pt@NiPcTs/C: Synthesis, structural and electro-oxidation for methanol", Catal. Commun. 10(8), 1271-1274 (2009). http://dx.doi.org/ 10.1016/j.catcom.2009.02.006

[3] Y. Zhang, M. Janyasupab, C. W. Liu, X. X. Li, J. Q. Xu and C. C. Liu, "Three dimensional PtRh alloy porous nanostructures: tuning the atomic composition and controlling the morphology for the application of direct methanol fuel cells", Adv. Funct. Mater. 22(17), 3570-3575 (2012). http://dx.doi.org/ 10.1002/adfm. 201200678

[4] J. Zeng, C. Francia, C. Gerbaldi, M. A. Dumitrescu, S. Specchia and P. Spinelli, "Smart synthesis of hollow core mesoporous shell carbons (HCMSC) as effective catalyst supports for methanol oxidation and oxygen reduction reactions", J. Solid Electrochem. 16(9), 3087-3096 (2012). http://dx.doi. org/10.1007/s10008-012-1750-3

[5] Y. C. Zhao, X. L. Yang, J. N. Tian, F. Y. Wang and L. Zhan, "Methanol electro-oxidation on Ni@Pd coreshell nanoparticles supported on multi-walled carbon nanotubes in alkaline media", Int. J. Hydrogen Energ. 35(8), 3249-3257 (2010). http://dx.doi.org/10. 1016/j.ijhydene.2010.01.112

[6] J. Rossmeisl, P. Ferrin, Tritsaris and A. Georgios, "Bifunctional anode catalysts for direct methanol fuel cells", Energ. Environ. Sci. 5(8), 8335-8342 (2012). http://dx.doi.org/10.1039/c2ee21455e

[7] T. Tomai, Y. Kawaguchi, S. Mitani and I. Honma, "Pt sub-nano/nanoclusters stabilized at the edge of nanographene sheets and their catalytic performance", Electrochim. Acta 92, 421-426 (2013). http://dx.doi. org/10.1016/j.electacta.2013.01.067

[8] S. A. Tenney, B. A. Cagg, M. S. Levine, W. He, K. Manandhar and D. A. Chen, "Enhanced activity for supported Au clusters: methanol oxidation on $\mathrm{Au} / \mathrm{TiO}_{2}(110)$ ", Sur. Sci. 606(15-16), 12331243 (2012). http://dx.doi.org/10.1016/j.susc. 2012.04 .002

[9] J. Z. Sun, Y. Z. Wang, C. Zhang, T. Y. Kou and Z. H. Zhang, "Anodization driven enhancement of catalytic activity of $\mathrm{Pd}$ towards electro-oxidation of methanol, ethanol and formic acid", Electrochem. Commun. 21, 42-45 (2012). http://dx.doi.org/10. 1016/j.elecom. 2012.04.023

[10] G. Z. Hu, F. Nitze, H. R. Barzegar, T. Sharifi, A. Mikołajczuk, C. W. Tai, A. Borodzinski and T. Wåberg, "Palladium nanocrystals supported on helical carbon nano?bers for highly ef?cient electro-oxidation of formic acid, methanol and ethanol in alkaline electrolytes", J. Power Sources 209, 236-242 (2012). http://dx.doi.org/10.1016/j. jpowsour. 2012.02.080

[11] I. Palacio, J. M. Rojo and O. Rodriguez de la Fuente, "Surface defects activating new reaction paths: formation of formate during methanol oxidation on Ru(0001)", ChemPhysChem 13(9), 2354-2360 (2012). http://dx.doi.org/10.1002/cphc. 201200190

[12] Y. Zhao, Y. Zhou, R. O'Hayre and Z. Shao, "Electrocatalytic oxidation of methanol on Pt catalyst supported on nitrogen-doped graphene induced by hydrazine reduction", J. Phys. Chem. Solids 74(11), 1608-1614 (2013). http://dx.doi.org/10. 1016/j.jpcs. 2013.06.004

[13] Y. T. Liu, Q. B. Yuan, D. H. Duan, Z. L. Zhang, X. G. Hao, G. Q. Wei and S. B. Liu, "Electrochemical activity and stability of core-shell $\mathrm{Fe}_{2} \mathrm{O}_{3} / \mathrm{Pt}$ nanoparticles for methanol oxidatio", J. Power Sources 243, 622-629 (2013). http://dx.doi.org/10.1016/j. jpowsour. 2013.06.029

[14] A. B. A. A. Nassr, I. Sinev, W. Grünert and M. Bron, "PtNi supported on oxygen functionalized carbon nanotubes: In depth structural characterization and activity for methanol electrooxidation", Appl. Catal. B: Envir. 142-143, 849-860 (2013). http://dx.doi.org/ $10.1016 / j$.apcatb. 2013.06.013

[15] M. Takahashi, T. Mori, F. Ye and A. Vinu, "A study of formaldehyde formation during methanol oxidation over PtRu bulk alloys and nanometer scale catalyst", J. Am. Ceram. Soc. 90(4), 1291-1294 (2007). http:// dx.doi.org/10.1111/j.1551-2916.2006.01483.x

[16] X. L. Yang, X. Y. Wang, G. Q. Zhang, J. P. Zheng, T. S. Wang, X. Z. Liu, C. Y. Shu, L. Jiang and C. N. Wang, "Enhanced electrocatalytic performance for methanol oxidation of $\mathrm{Pt}$ nanoparticles on $\mathrm{Mn}_{3} \mathrm{O}_{4}$ modifiedmulti-walled carbon nanotubes", Int. J. Hydrogen Energ. 37(15), 11167-11175 (2012). http://dx . doi.org/10.1016/j.ijhydene. 2012.04.153

[17] X. W. Xie, Y. Li, Z. Q. Liu, M. Haruta and W. J. Shen, "Low-temperature oxidation of $\mathrm{CO}$ catalysed by $\mathrm{Co}_{3} \mathrm{O}_{4}$ nanorods", Nature 458, 746-749 (2009). http://dx.doi.org/10.1038/nature07877

[18] C. Liu, Q. Liu, L. Bai, A. Dong, G. Liu and S. Wen, "Structure and catalytic performances of nanocrystalline $\mathrm{Co}_{3} \mathrm{O}_{4}$ catalysts for low temperature $\mathrm{CO}$ oxidation prepared by dry and wet synthetic routes", J. Molecular Catal. A: Chem. 370, 1-6 (2013). http:// dx.doi.org/10.1016/j.molcata. 2012.12.003

[19] G. Marbán, I. López, T. Valdés-Solís and A. B. Fuertes, "Highly active structured catalyst made up of mesoporous $\mathrm{Co}_{3} \mathrm{O}_{4}$ nanowires supported on a metal wire mesh for the preferential oxidation of CO", Int. J. Hydrogen Energ. 33(22), 6687-6695 (2008). http:// dx.doi.org/10.1016/j.ijhydene. 2008.07.067

[20] C. W. Xu, Z. Q. Tian, P. K. Shen and S. P. Jiang, "Oxide $\left(\mathrm{CeO}_{2}, \mathrm{NiO}, \mathrm{Co}_{3} \mathrm{O}_{4}\right.$ and $\left.\mathrm{Mn}_{3} \mathrm{O}_{4}\right)$ promoted $\mathrm{Pd} / \mathrm{C}$ electrocatalysts for alcohol electrooxidation in alkaline media", Electrochim. Acta 53(5), 2610-2618 (2008). http://dx.doi.org/10.1016/j. electacta.2007.10.036

[21] Y. Y. Huang, J. D. Cai, S. Y. Zheng and Y. L. Guo, "Fabrication of a high-performance $\mathrm{Pb}-\mathrm{PtCu} / \mathrm{CNT}$ catalyst for methanol electro-oxidation", J. Power Sources 210, 81-85 (2012). http://dx.doi.org/10. $1016 / j \cdot j$ powsour . 2012.03.002 
[22] S. W. Li, X. L. Yu, G. J. Zhang, Y. Ma and J. N. Yao, "Green synthesis of a Pt nanoparticle/polyoxometalate/carbon nanotube tri-component hybrid and its activity in the electrocatalysis of methanol oxidation", Carbon 49(6), 1906-1911 (2011). http://dx.doi.org/10.1016/j.carbon.2011.01.015

[23] R. J. Liu, S. W. Li, X. L. Yu, G. J. Zhang, S. J. Zhang, J. N. Yao and L. J. Zhi, "A general green strategy for fabricating metal nanoparticles/polyoxometalate/graphene tri-component nanohybrids: enhanced electrocatalytic properties", J. Mater. Chem. 22, 3319-3322 (2012). http://dx. doi.org/10.1039/c2jm15875b

[24] C. Z. Yang, N. K. van der Laak, K. Y. Chan and X. Zhang, "Microwave-assisted microemulsion synthesis of carbon supported Pt- $\mathrm{WO}_{3}$ nanoparticles as an electrocatalyst for methanol oxidation", Electrochim. Acta 75, 262-272 (2012). http://dx.doi.org/10.1016/j. electacta.2012.04.107

[25] C. Lamy and E. M. Belgsir, J. M. Léger, "Electrocatalytic oxidation of aliphatic alcohols: Application to the direct alcohol fuel cell (DAFC)", J. Appl. Elec- trochem. 31(7), 799-809 (2001). http://dx.doi.org/ 10.1023/A : 1017587310150

[26] J. M. pérez, B. Beden, F. Hahn, A. Aldaz, C. Lamy, "In situ" infrared reflectance spectroscopic study of the early stages of ethanol adsorption at a platinum electrode in acid medium", J. Electronanal. Chem. 262(1-2), 251-261 (1989). http://dx.doi.org/ 10.1016/0022-0728 (89)80026-9

[27] H. Hitmi, E. M. Belgsir, J. M. Léger, C. Lamy and R. O. Lezna, "A kinetic analysis of the electro-oxidation of ethanol at a platinum electrode in acid medium", Electrochim. Acta 39(3), 407-415 (1994). http://dx. doi .org/10.1016/0013-4686(94)80080-4

[28] J. Jansson, "Low-Temperature CO Oxidation over $\mathrm{Co}_{3} \mathrm{O}_{4} / \mathrm{Al}_{2} \mathrm{O}_{3} "$, J. Catal. 194(1), 55-60 (2000). http://dx.doi.org/10.1006/jcat.2000.2924

[29] Z. L. Zhang, H. R. Geng, L. S. Zheng and B. $\mathrm{Du}$, "Characterization and catalytic activity for the $\mathrm{NO}$ decomposition and reduction by $\mathrm{CO}$ of nanosized $\mathrm{Co}_{3} \mathrm{O}_{4}$ ", J. Alloy. Compd. 392(1-2), 317321 (2005). http://dx.doi.org/10.1016/j.jallcom. 2004.09 .013 